\title{
Plio-Pleistocene Landscape Evolution of the Turano River Basin (Central Apennines, Italy): Insights from Continental Deposits' Analysis and Drainage Network Development
}

\author{
Vania Mancinelli ${ }^{1}(0)$, Gian Paolo Cavinato ${ }^{2}$, Francesco Ciavattella ${ }^{1}$, Alessandro Cecili ${ }^{3}$, Maurizio D'Orefice ${ }^{4}$, \\ Carmela Epifani ${ }^{1}$, Gianluca Esposito ${ }^{1}\left(\mathbb{D}\right.$, Massimiliano Fazzini ${ }^{1}$, Giorgio Paglia $\left.{ }^{1}{ }^{(}\right)$, Maurizio Parotto ${ }^{2}$ \\ and Enrico Miccadei $1,5, * \mathbb{B}$
}

1 Department of Engineering and Geology, Università degli Studi "G. d'Annunzio" Chieti-Pescara, Via dei Vestini 31, 66100 Chieti Scalo, Italy; vania.mancinelli@unich.it (V.M.); f.ciavattella@gmail.com (F.C.); epifanicarmen@gmail.com (C.E.); gianluca.esposito@unich.it (G.E.); massimiliano.fazzini@unich.it (M.F.); giorgio.paglia@unich.it (G.P.)

2 CNR-Institute of Environmental Geology and Geoengineering, Sede di Roma, Sapienza Università di Roma, P. le Aldo Moro 5, 00185 Roma, Italy; gianpaolo.cavinato@igag.cnr.it (G.P.C.); silvmau.parotto@gmail.com (M.P.)

3 GIS Laboratory, Department of Sciences, Roma Tre University, Largo San Leonardo Murialdo 1, 000146 Roma, Italy; ceciliroma3@gmail.com

check for updates

Citation: Mancinelli, V.; Cavinato, G.P.; Ciavattella, F.; Cecili, A.;

D'Orefice, M.; Epifani, C.; Esposito,

G.; Fazzini, M.; Paglia, G.; Parotto, M.; et al. Plio-Pleistocene Landscape

Evolution of the Turano River Basin (Central Apennines, Italy): Insights from Continental Deposits' Analysis and Drainage Network Development. Geosciences 2021, 11, 245. https://doi.org/10.3390/ geosciences11060245

Academic Editors: Piotr Migoń and Jesus Martinez-Frias

Received: 3 May 2021

Accepted: 2 June 2021

Published: 5 June 2021

Publisher's Note: MDPI stays neutral with regard to jurisdictional claims in published maps and institutional affiliations.

Copyright: (C) 2021 by the authors Licensee MDPI, Basel, Switzerland. This article is an open access article distributed under the terms and conditions of the Creative Commons Attribution (CC BY) license (https:// creativecommons.org/licenses/by/ $4.0 /)$.
4 Department for the Geological Survey of Italy, Italian Institute for Environmental Protection and Research, ISPRA, Via Vitaliano Brancati 48, 00144 Roma, Italy; maurizio.dorefice@isprambiente.it

5 Istituto Nazionale di Geofisica e Vulcanologia (INGV), Sezione Roma 1, Via di Vigna Murata 605 , 00143 Roma, Italy

* Correspondence: enrico.miccadei@unich.it

Abstract: Quaternary continental deposits record spatio-temporal changes of the landscape and offer insights for drainage network analysis and paleoenvironmental reconstructions. This paper focuses on the Turano River, a left tributary of the Velino River, which flows in the southwestern Abruzzo area at the boundary with Lazio Region. Its basin preserves lithological and morphological field evidence particularly suitable for reconstructing the long-term geomorphological evolution of the Central Apennines and the drainage network development. In detail, the Turano River was investigated through a drainage basin-scale analysis incorporating morphometric analysis, field mapping, continental deposits analysis, and integrated drainage network analysis. This approach allowed us to define a drainage network reversal process, clearly highlighted by the spatial arrangement of continental deposits, spanning from Upper Pliocene to Holocene. The results also indicated tectonic activity as the main factor driving incision and river inversion processes. The work contributes to identifying and describing the main steps of the Quaternary landscape evolution of this mountainous catchment and its morphoneotectonic framework. Therefore, it could represent a methodological tool for multidisciplinary studies in similar mountainous catchments to support any territorial planning activity, from large infrastructure localization (i.e., artificial dams) to sustainable land management.

Keywords: Plio-Pleistocene continental deposits; tectonics; paleo-drainage; landscape evolution; Turano River; Central Apennines

\section{Introduction}

The present-day landscape results from the dynamic interaction between geological and geomorphological processes that have contributed to its long-term evolution, providing information on past morphogenetic events [1]. Landscape evolution appears complex and diverse in space and time, especially in young and active mountain chains (such as Central Apennines), mainly responding to tectonic events, geomorphological processes, and environmental changes (i.e., volcanic events, climate oscillations, and related sealevel changes) [2-5]. Central Apennines are an asymmetrical NW-SE-oriented mountain 
chain characterized by alternating calcareous ridges, valleys on pelitic-arenaceous deposits, and intermontane basins filled by Quaternary continental deposits. This mountainous environment is the result of the competition between tectonics and surface processes, controlled by climate, eustasy, and lithology distribution [6-9]. In detail, the resulting landscape is directly linked to a dynamic evolution that occurred in ensuing stages with the interaction between morphostructural factors (i.e., conflicting tectonic activity and regional uplift) and morphosculptural factors (i.e., drainage network development and gravitational phenomena) [10-12]. The regional geological-geomorphological framework has been widely studied by several authors [e.g., [11,13-19]]; however, the relationships between paleo-drainage, continental deposits, and landscape dynamics are still not fully understood, particularly with regards to the role played on drainage systems' evolution.

Field evidence inherited from paleo-drainage (such as paleochannels and paleocurrents), integrated with lithological analysis, offers significant advances to decipher the multitemporal evolution of drainage basins and floodplains [20,21]. Moreover, in tectonically active landscapes, drainage systems evolve in response to tectonic-geomorphological changes and are highly sensitive to structural control [22-25]. The detailed analysis of fluvial network rearrangements provides a key to understanding Quaternary landscape evolution in these dynamic frameworks. Moreover, the multidisciplinary study of river valleys, performed using GIS-based techniques, provides knowledge of the evolution of the fluvial landscape and is a fundamental approach for understanding current geomorphological processes.

Starting from these general considerations, this work focuses on the investigation of the drainage network evolution of the Turano River basin, located at the boundary between Abruzzo and Lazio regions (Central Italy). It presents the results of a preliminary synthesis and analysis of Plio-Pleistocene continental deposits, performed through detailed analysis on essential data already available and recently verified by geological-geomorphological field surveys. Morphometric analysis was carried out to better characterize drainage network features. The resulting correlations between geological data and fluvial environment allowed us to reconstruct the main steps of the Quaternary landscape evolution of this mountainous catchment. The final aim of our study was the application of an integrated and multidisciplinary methodology to improve knowledge about the relationships between paleo-drainage, continental deposits, and landscape dynamics, giving an additional contribution to the general knowledge on the Central Apennines.

\section{Study Area}

The Turano River is a left tributary of the Velino River valley, located in Central Italy at the boundary between the Lazio and the Abruzzo Apennines (Figure 1a). A mountainous landscape characterizes the Central Apennine chain area (with reliefs up to $2900 \mathrm{~m}$ a.s.l. high; i.e., Sibillini Mts., $2476 \mathrm{~m}$ a.s.l.; Gran Sasso Massif, $2912 \mathrm{~m}$ a.s.l.; Maiella Massif, $2793 \mathrm{~m}$ a.s.l.), interrupted by longitudinal and transversal river valleys and wide intermontane basins (i.e., Rieti, L'Aquila, Fucino, and Sulmona basins). The chain gently drops down to the hilly-piedmont areas (ranging from $\sim 600 \mathrm{~m}$ a.s.l. to the coastline), towards both the Adriatic and Tyrrhenian sides (Figure 1b).

The geological framework is the result of the Neogene-Quaternary evolution of an orogenic system (chain-foredeep-foreland) migrating eastward [26]. The major thrust systems, NW-SE and N-S-oriented and gently dipping towards SW, were stacked on each other, involving different structural and paleo-geographical domains (carbonate platforms and related margins, slope, and pelagic basin) featuring different tectonic orientations. Since the Early Pleistocene, the orogen underwent regional uplifting and, contemporaneously, local extensional tectonics determined the development of several tectonic basins, mainly bordered by NW-SE-oriented and SW-dipping normal to transtensional faults [27-31]. Furthermore, in the same period, the coincidence of volcano-tectonic and tectonic-sedimentary events contributed to the evolution of the Tyrrhenian hinterland, including large peri-Tyrrhenian volcanic districts and basins [32-34]. The direct combina- 
tion of tectonic processes (i.e., Miocene-Pliocene thrusting and Quaternary extensional tectonics), regional uplift, and geomorphological processes (e.g., slope, fluvial, karst, and glacial processes) resulted in the reorganization of drainage systems and intermontane basins, development of several valleys with flights of fluvial terraces, and formation of the present-day landscape $[5,7,16,35,36]$.

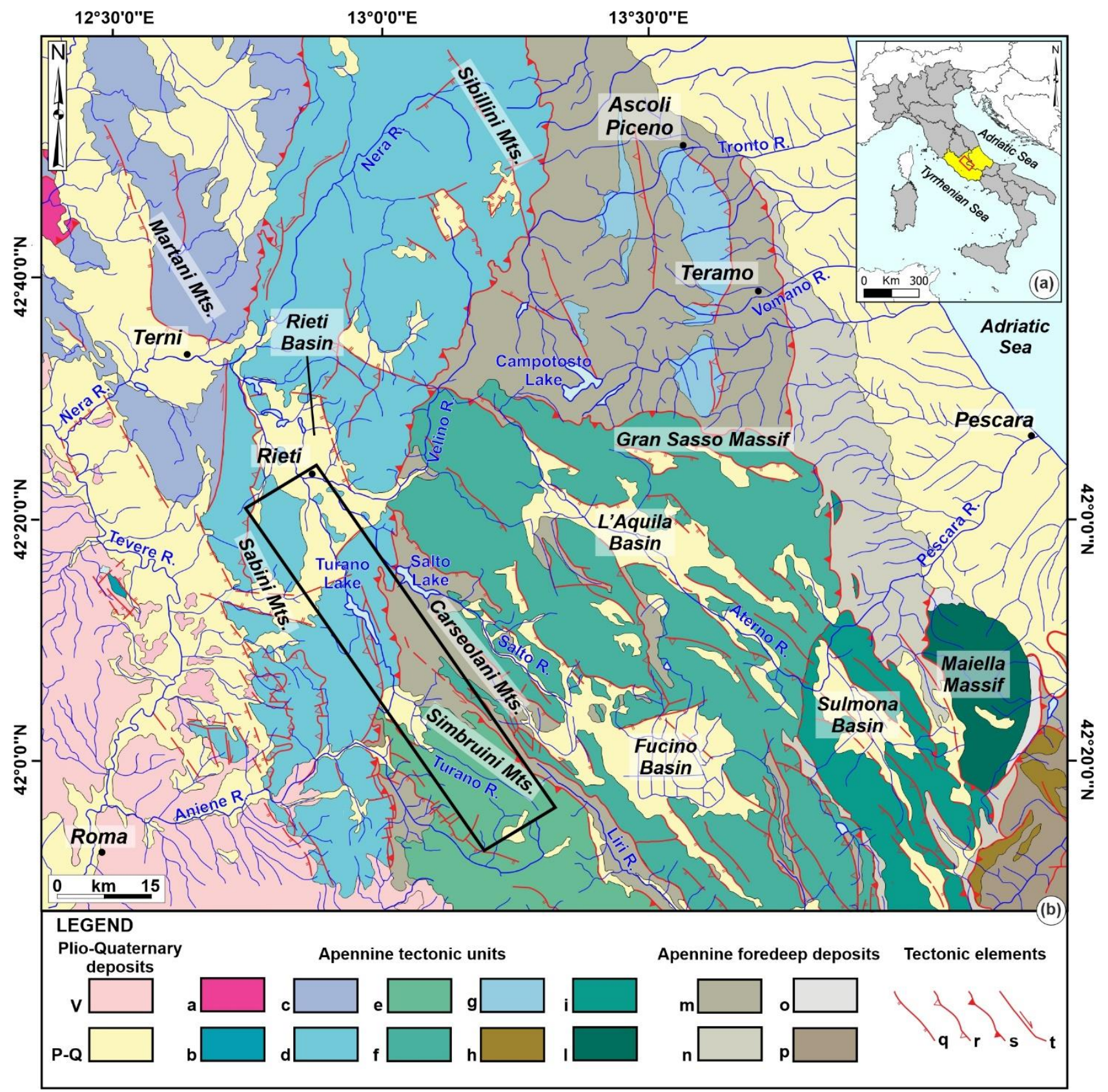

Figure 1. (a) Location map of the study area (red box) in Central Italy; (b) simplified structural map of Central Apennines (modified from [9]). Legend: (V) Volcanic deposits; (P-Q) Plio-Quaternary marine and continental deposits; (a) External Ligurian unit; (b) Mt. Soratte tectonic unit; (c) Inner Umbria tectonic unit; (d) Umbria-Marchean-Sabine tectonic unit; (e) Simbruini-Ernici tectonic unit; (f) Gran Sasso-Western Marsica tectonic unit; (g) Acquasanta-Montagnone tectonic unit; (h) Molise tectonic unit; (i) Morrone-Eastern Marsica tectonic unit; (l) Maiella tectonic unit; (m) Messinian foredeep deposits; (n) Upper Messinian-Lower Pliocene foredeep deposits; (o) Lower Pliocene foredeep deposits; (p) Molise allochthonous deposits; (q) normal fault; (r) minor thrust; (s) major thrust; (t) strike-slip fault. The black box represents the study area. 
The Turano River valley is a hilly-mountainous area with a wavy and irregular morphology that progressively drops down in elevation, moving towards the Rieti Plain. The Turano River flows in a SE-NW direction along one of the main drainage divides of the chain area, between the Fucino and the Rieti basins. Its drainage basin shows an elongated and irregular shape, and it is spatially limited by the reliefs belonging to the Carseolani, Simbruini, and Sabini mountain chains. The Turano dam stands out in the middle sector of the valley and blocks the river course, giving rise to the homonymous lake. It is an integral part of a huge complex of hydroelectric plants located along the main course of the neighbouring Nera and Velino rivers. It was designed during the 1920s and realized in a brief period (from 1936 to 1938). The reservoir shows a storage capacity of $163 \mathrm{Mm}^{3}$, and it is hydraulically connected, with a $9 \mathrm{~km}$ long tunnel, to the artificial Salto Lake $[37,38]$. Moreover, an estimation of the total reservoir sedimentation (resulting from bathymetric surveys in 1997-2005 time) amounted to $12.296 \mathrm{M} \mathrm{m}^{-3}$, with a calculated annual sediment yield of about $1.537 \mathrm{M} \mathrm{m}^{-3}$, assuming a linear temporal distribution $[39,40]$.

From a geological viewpoint, the study area is characterized by the outcropping of carbonate shelf limestones and dolomites, slope limestones, basin limestone, and marls, pertaining to Umbria-Marchean-Sabine and Simbruini-Ernici units. Sandy-pelitic turbidites and clayey-sandy deposits, belonging to the Apennine foredeep units, are mainly widespread in the central sectors of the area (Figure 1b). Plio-Pleistocene deposits broadly characterize the Turano River basin and surrounding areas, as reported by several studies concerning the stratigraphy of the main intermontane basins of Central Apennines $[9,28,41-45]$. These deposits are widely present along the valley bottoms, the main slopes, and in correspondence of the main basins (i.e., Carsoli and Rieti plains) [46-51]. In detail, lithological successions were deposited in a transitional paleogeographic domain between the Latium-Abruzzi carbonate platform and the Umbria-Marchean-Sabine pelagic basins. Bedrock lithologies are predominantly composed of calcareous, marly-calcareous, detrital marly deposits, and arenaceous-conglomeratic turbiditic deposits pertaining to Meso-Cenozoic lithological sequences (Figure 2a). Continental deposits are distinguished in different units (Synthems and/or Supersynthems) according to their lithological characteristics and related ages. They consist of sandy and silty-clayey deposits with heterometric calcareous and arenaceous gravels, mainly referable to fluvio-lacustrine environments, talus, scree slopes, and alluvial domains (Figure 2b).

The present-day regional tectonic setting is mainly dominated by extensional tectonics still active in the axial part of the Apennines chain, which has been affected by both historical and recent strong seismicity [52]. In detail, the area strongly resented the shaking effects induced by several earthquakes with Mw up to 7.0 (e.g., Fucino 1915; L'Aquila 2009; Central Italy 2016-2017). 


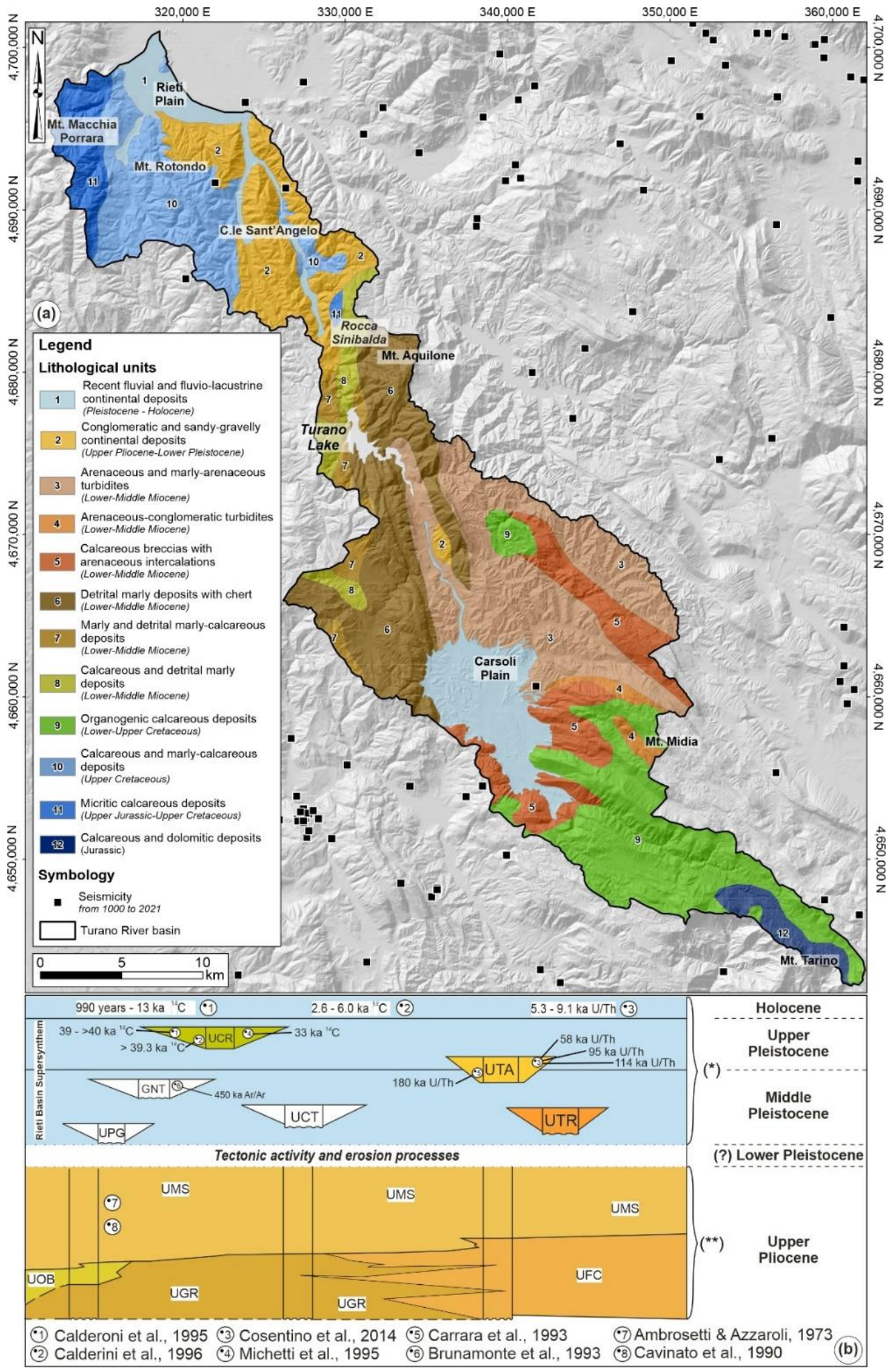

Figure 2. (a) Simplified lithological map of the Turano River Basin (modified and integrated with [41,47]). Seismicity-CPTI15 catalogue [52] and ISIDe database [53] (black square); (b) stratigraphic scheme of the Plio-Pleistocene continental deposits of the Turano River basin and surrounding areas (modified from [54]). Note: $\left({ }^{*}\right)$ colour refers to Lithological unit 1 . This unit includes several sub-units: UTR, UCT, UPG, GNT, UTA, and UCR; $\left({ }^{* *}\right)$ colours mainly refer to lithological unit 2 . This unit includes several sub-units: UFC, UGR, UOB, and UMS. 


\section{Materials and Methods}

The Turano River Basin was investigated through a drainage network analysis incorporating (i) morphometric analysis, (ii) field mapping, (iii) continental deposits analysis, and (iv) integrated drainage network analysis. It was carried out using topographic maps (1:25,000-1:5000 scale), retrieved from Open Geodata Portal of Lazio and Abruzzo Region, and supported by the use of a 10 m TINITALY Digital Elevation Model (http: //tinitaly.pi.ingv.it/ [55,56]-accessed on 5 September 2020). Morphometric analysis was carried out in geographic information system (GIS) software (ArcMap ${ }^{\circledR}$ 10.6, ESRI, Redlands, CA, USA). The orographic analysis was based on the definition of the main orographic parameters, such as elevation and slope (first derivate of elevation [57]). The hydrographic analysis was focused on the detailed definition of the drainage network features. Basin boundaries and drainage lines were automatically derived from DEM data using "Hydrology Tool" in ArcMap and verified by means of topographic maps and air photos (Google Earth, 2019). According to Strahler [58], the drainage network was hierarchized, and the azimuthal orientations of drainage lines were derived by automatic GIS procedures. Then, according to the length of the streams (lines' segmentation at each stream junction, as obtained from GIS analysis-allowing the actual distribution to be better detected), they were analyzed using frequency-weighted rose diagrams [59,60]. Field mapping was conducted at an appropriate scale (1:5000-1:10,000), according to Italian geological guidelines [61] and the thematic literature concerning geological-geomorphological mapping, as well as field-based and numerical analysis [62-68]. It focused on mapping and describing the spatial distribution of continental deposits and tectonic elements, omitting bedrock lithologies. According to thematic literature $[28,69,70]$, Plio-Pleistocene stratigraphic frameworks have been recognized as a fundamental tool to chronologically constrain geological paleo-events, with significant implications in neotectonics and in the reconstruction of different paleoenvironments. Therefore, a detailed analysis of Plio-Pleistocene continental deposits of the basin and surrounding areas was performed. These deposits were defined as UBSU, combining our lithological units with those previously recognized in the thematic literature $[41,47,50,71]$ and by means of stratigraphic correlations between geological sheets of CARG Project [72-76]. The more detailed field surveying scale allowed us to clearly map continental deposits' outcrops and define some tectonic and stratigraphic features. Field surveys were integrated with literature data and stratigraphic observations to constrain and correlate continental deposits and their spatial distribution throughout the basin.

The drainage network development was discussed and analysed by realising a generalized longitudinal profile segment of the present-day Turano River, projecting the spatial arrangement of continental deposits to show the main drainage directions graphically. Different continental deposits were mapped according to their relative height above the bottom valley and their morphological continuity. Each feature is located along with the profile according to its distance from the outlet, and the symbols are plotted considering the projected angle with the valley axis [77-79]. Discretely preserved deposits' remnants have been correlated along the Turano River with locations displayed in the distance from source $[\mathrm{km}]$ and elevations above sea level $[\mathrm{m}]$. This approach allowed us to correlate the relationships between present-day drainage network, anomalies in the distributions of continental deposits, and tectonic elements, providing geomorphological constraints in the timing of landscape evolution and drainage network reversal process.

\section{Results}

\subsection{Morphometric Analysis}

The study area reaches its maximum altitude on the relief of Mt. Tarino (1961 m a.s.l.), along the southeastern divide, while to the north, the morphology slopes down gradually towards the Carsoli Plain and the Turano Lake; then, it drops down to a minimum of $370 \mathrm{~m}$ a.s.l. in the southern sector of Rieti Plain.

Different physiographic sectors can be recognized in the study area, through the analysis of landscape morphological features (such as elevation and slope; Figure 3). The 
southern sector is characterized by a typical mountainous landscape, whose orography is dominated by the main ridges, NW-SE-oriented, representing the divide of the basin and including the main reliefs of the area (i.e., Mt. Midia, $1737 \mathrm{~m}$ a.s.l.; Mt. Morbano, $1823 \mathrm{~m}$ a.s.l.). Slope values' distribution is strictly homogenous (values between $20^{\circ}$ and $45^{\circ}$ ), and the highest values $\left(>55^{\circ}\right)$ are concentrated along the southwestern slopes of Mt. Morbano ridge. The central sector shows a hilly-mountainous landscape with elevations ranging from 500 to $1500 \mathrm{~m}$ a.s.l., and it is dominated and interrupted by wide flat areas (Carsoli Plain and Turano lake area) and isolated reliefs (i.e., Mt. Navegna, $1508 \mathrm{~m}$ a.s.l.; Mt. Cervia, $1438 \mathrm{~m}$ a.s.1.; Mt. Aquilone, $1337 \mathrm{~m}$ a.s.1.). The Carsoli Plain is roughly elliptical and shows an altitude ranging between about $560 \mathrm{~m}$ and $690 \mathrm{~m}$ a.s.l., while the lake area is located at $530 \mathrm{~m}$ a.s.l. Slope values range from $\sim 5^{\circ}$, in correspondence of planar surfaces, to $35^{\circ}$ in areas of slight incline next to the Carsoli Plain, with highest values $\left(>60^{\circ}\right)$ along the steep slopes surrounding the lake and the minor and ephemeral stream channels, which flow in the W-E direction.
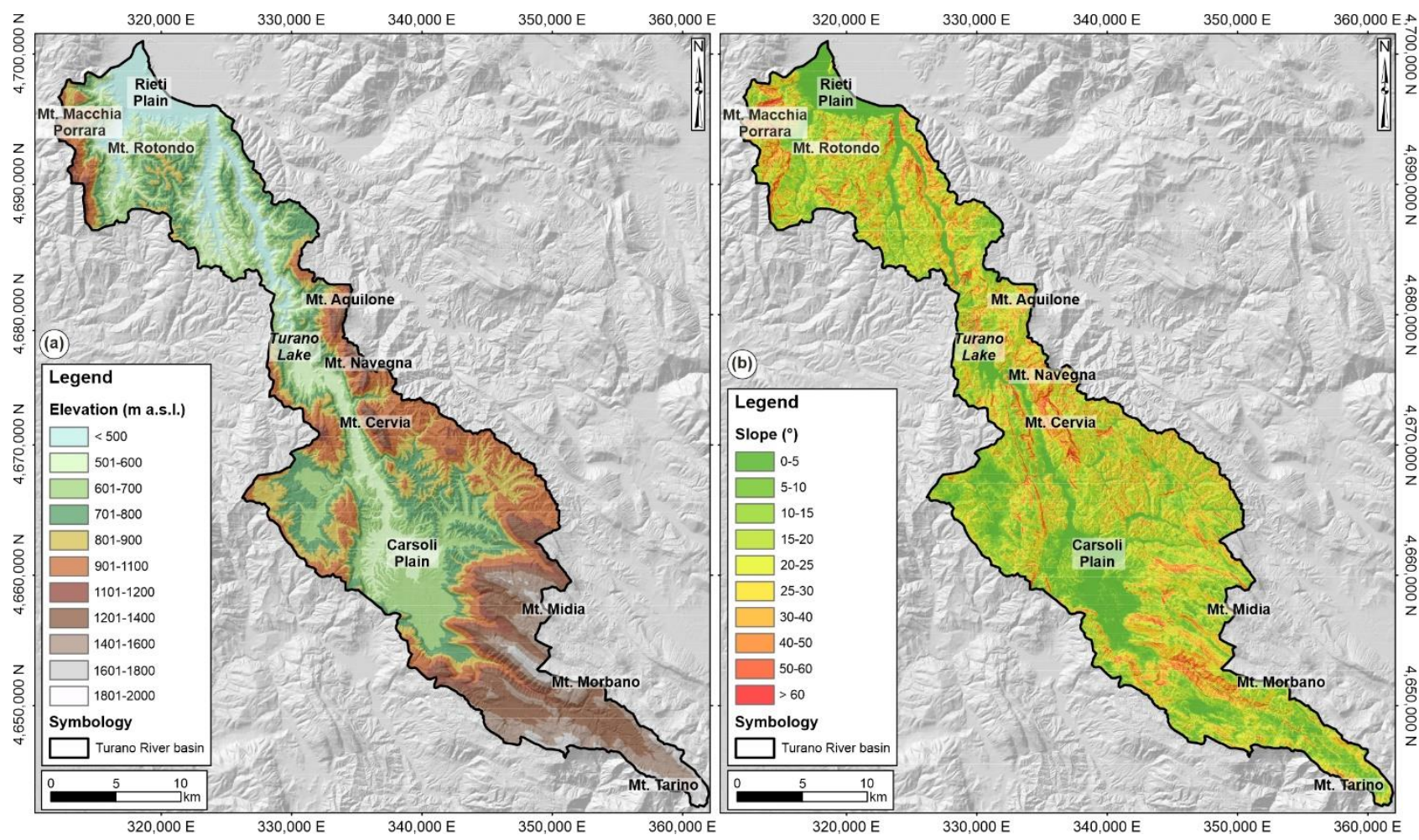

Figure 3. Physiographic features of the study area: (a) elevation map; (b) slope map.

The northern sector extends itself from the Turano dam towards the Rieti Plain, with elevations ranging from 400 to $1200 \mathrm{~m}$ a.s.l. It shows a wavy and irregular morphology interrupted by ridges and isolated reliefs (i.e., Mt. Macchia Porrara, $1202 \mathrm{~m}$ a.s.l.; Mt. Rotondo, $841 \mathrm{~m}$ a.s.l.), and the meandering course of the river. Slope values range from $\sim 5^{\circ}$, in the Rieti Plain, to $30^{\circ}$ in areas of a slight incline, with the highest values $\left(>55^{\circ}\right)$ along the steep slopes of minor stream channels, which flow in E-W direction in correspondence of the eastern division.

\subsection{Continental Deposits}

Continental deposits were classified into 17 separate units spanning from Upper Pliocene to Holocene, as graphically shown in Figure 4. These units were identified, mapped, and correlated throughout the basin by combining lithological features, age, depositional environment, and different behaviours towards drainage network processes. Therefore, the outcropping deposits were distinguished as follows: 
- Upper Pliocene-Lower Pleistocene deposits (units from 2e to 2a);

- Middle Pleistocene deposits (units from $1 n$ to 11 );

- $\quad$ Upper Pleistocene-Holocene deposits (units from 1i to 1a).

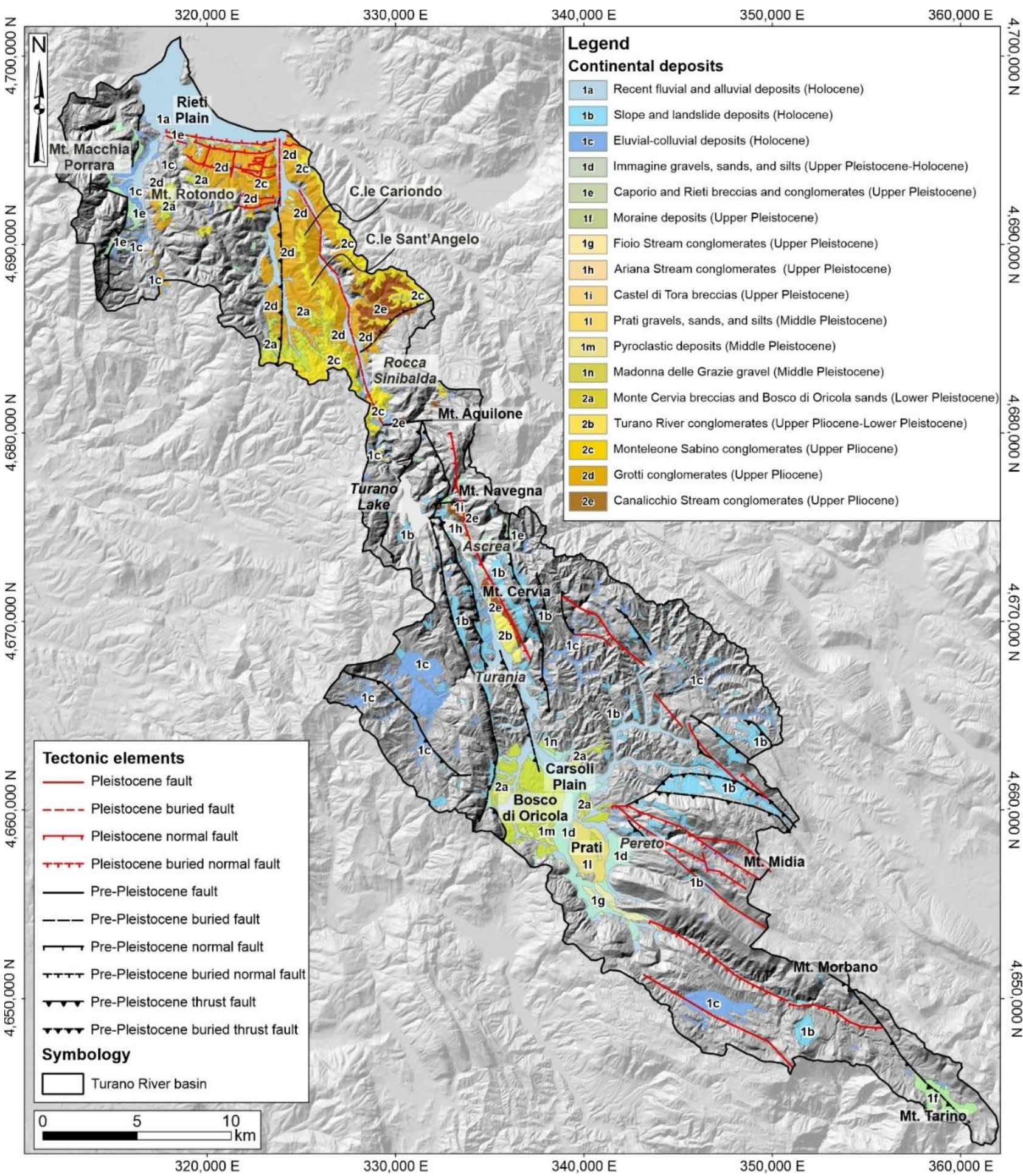

Figure 4. Plio-Pleistocene geological map of the Turano River basin. Note: numbers from 1a to 1n refer to lithological unit 1 in Figure 2a; numbers from 2a to 2e refer to lithological unit 2 in Figure 2a.

The first continental depositional event corresponds to conglomeratic and sandy units, spanning from Upper Pliocene to Lower Pleistocene, which includes deposits pertaining 
to different environments related both to the fluvial system and lacustrine environment. Heterometric gravels and conglomerates with intercalated fine-grained sediments represent fluvial system-related deposits (Figure 5a,b). Well-sorted arenaceous to calcareous conglomerates supported by sandy-silty matrix (Figure $5 c$ ) mainly outcrop along the meandering course of the Turano River, interbedded with lacustrine sands, sandy-silty marls, clays, and thin calcarenite layers. Massive calcareous breccias, interbedded at several stratigraphical levels, are also present. These deposits are well preserved in the northwestern sector of the basin moving towards the Rieti Plain, in correspondence with the wavy and irregular morphology interrupted by the N-S-oriented C.le Cariondo-C.le Sant'Angelo ridge and the isolated reliefs of Rocca Sinibalda; while in the southeastern sector, they outcrop discontinuously, near Turania and the southwestern flank of Mt. Cervia. Lacustrine environment is highlighted by the presence of fine-grained (silt and clay) sediments. These units are organized in well-stratified alternates of grey-blue clayey-silty and yellowish silty-sandy layers (Figure 5d). They represent the most ancient continental deposits within the Carsoli Plain, outcropping with a certain continuity in its northwestern and central sectors. Limited outcrops can also be observed in the northern sector of the basin, near Mt. Rotondo.
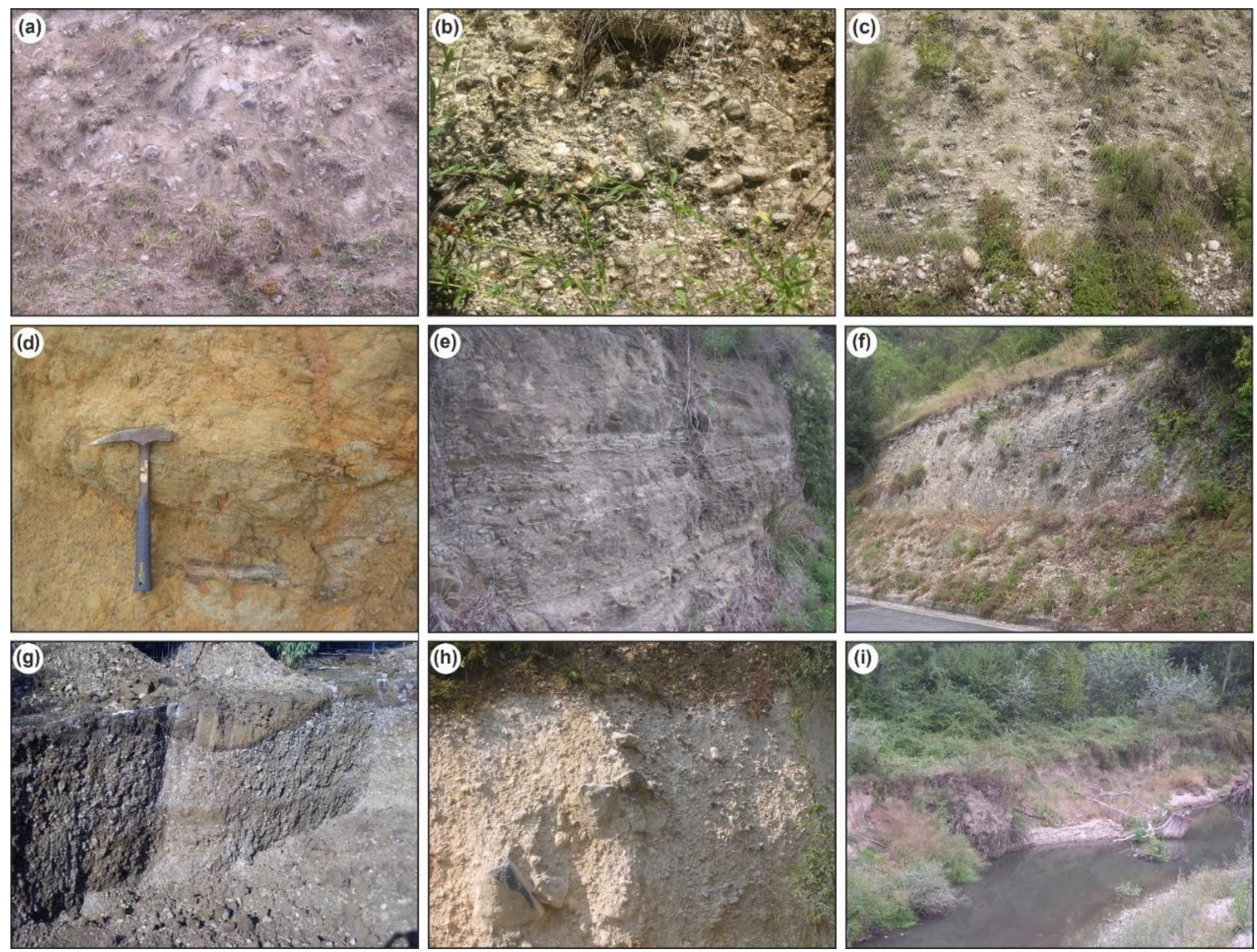

Figure 5. Photo documentation of continental deposits. (a) Coarse loose conglomeratic deposits-2e; (b) heterometric gravelly and conglomeratic deposits—2c; (c) heterometric conglomeratic deposits supported by sandy-silty matrix-2b; (d) alternances of grey-blue clayey-silty and yellowish silty-sandy deposits-2a; (e) fine to coarse grey cineritic with heterometric carbonate clasts-1m; (f) clast-supported massive conglomeratic deposits-1h; (g) heterometric calcareous gravelly deposits in sandy matrix - 1d; (h) slope and landslide deposits-1b; (i) recent fluvial and alluvial deposits-1a. Numbers (2e, 2c, 2b, 2a, 1m, 1h, 1d, 1b, 1a) refer to the legend in Figure 4. 
Middle Pleistocene deposits are mainly characterized by coarse-grained (gravel and sand) sediments, referring to fluvial and lacustrine environments. Heterometric and poorly sorted gravels with silty-clayey or sandy levels locally outcrop in the northernmost sector of the Carsoli Plain. A peculiar sequence of volcanic deposits, dated about $0.531 \mathrm{My}-$ $0.540 \mathrm{My}$ [3], shows a complex sequence of pyroclastic flow, surge, and airfall products. These pyroclastic deposits are local products connected with the evolution of a Middle Pleistocene intrapenninic monogenic volcanism. From a lithological viewpoint, these deposits are mainly characterized by a rhythmic succession of coarse and fine gray cineritic tuffs (Figure 5e) with lapilli and heterometric angular carbonate clasts, followed by reddish tuffs characterized by a dense alternation of fine and coarse cinerite levels. Significant outcrops are present in the southernmost sector of the plain at Bosco di Oricola. Coarsegrained gravel deposits with sandy-silty matrix rich in volcanic femic minerals widely outcrop in Prati area.

Upper Pleistocene-Holocene deposits are arranged in different units, mainly represented by coarse- (gravel, conglomerate, and sand) to fine-grained (silt and clay) deposits. Each unit incorporates deposits referable to different genetic geomorphological processes (i.e., slope, landslide, fluvial, alluvial fan, colluvial, and glacial). In detail, they are characterized by gravelly deposits, with heterometric, subangular to subrounded, carbonate clasts and sandy-silty levels, passing laterally to alluvial fan deposits consisting of clast-supported massive conglomerates (Figure $5 \mathrm{f}$ ). Heterometric coarse calcareous gravels, generally in a sandy matrix, with intercalated silty sands and dark clayey-sandy silts (Figure 5g), are widespread in the central and eastern sector (near Pereto) of the Carsoli Plain.

Holocene deposits can be distinguished in eluvial-colluvial deposits made up of sands, silts, and gravels containing alternating brown sands and well-rounded calcareous conglomerates from centimetric to decimetric size; slope and landslide deposits composed of gravel and loose heterometric conglomerates with sub-rounded calcareous clasts and chaotic material (Figure 5h). They are widely present throughout the basin in correspondence with the slopes of the main reliefs, as well as recent fluvial and alluvial deposits made up of silts, sands, and gravels with centimetric pebbles, largely present in the Rieti Plain, in the Turano River plain (Figure 5i), and along minor and ephemeral stream channels.

\subsection{Tectonic Elements}

The present-day tectonic setting is the result of different tectonic phases, occurring from Miocene to recent times, which mainly include a Mio-Pliocene compressional phase and a Pleistocene post-orogenic extensional phase, still active in the axial sector of Central Apennines [80]. More in detail, the Turano River basin is located at the transition zone between two interfering regional structural domains: the Umbro-Sabina transitional units (with a main N-S trend) and the Latium-Abruzzi carbonate platform (with NW-SE trends; [81]). These two structural domains are in tectonic contact along a series of thrust fronts known in the literature as the "Olevano-Antrodoco" line [82,83]. Strike-slip tectonics is also commonly documented in the study area. It contributed to defining the complex tectonic setting, deforming the compressional tectonic units, in addition with later extensional tectonic events. Available literature data indicate overall slip rates up to $0.5 \mathrm{~mm} /$ year, in agreement with information from paleosismological analyses, fault traces' monitoring, as well as geological data $[9,29,84]$. The main tectonic elements in the study area are represented by both thrust and normal faults, mainly arranged in N-S, E-W, NW-SE, and NE-SW-oriented fault systems. Based on abundant geological and structural literature information integrated with acquired field data and GIS-based techniques, it was possible to identify and map Plio-Pleistocene faults, as previously shown in Figure 4, distinguishing them into two categories: pre-Pleistocene and Pleistocene faults.

Pre-Pleistocene faults are mainly represented by thrust fronts, which trend roughly N-S and NW-SE in the northern and central-southern sectors, respectively. These tectonic elements are often not clearly observable, but their existence can be inferred through minor in-field exposures. 
Pleistocene faults broadly characterize the southernmost sector of the basin and the northernmost one, especially towards the Rieti Plain. In detail, the central and southern sectors are characterized by main fault system NW-SE, N-S, and E-W-oriented, referable to normal faults and faults of uncertain type. Important tectonic elements can be identified, as follows: the main fault system, roughly NW-SE-oriented in the southern sectors, which shows a complex tectonic evolution, as clearly highlighted in thematic literature [85]; the Ascrea fault, an NNW-SSE to N-S-oriented tectonic element with prevalent normal kinematics (Figure 6a,b, [86]), whose trend can be recognized with a clear continuity in the central sector of the basin along the southwestern flank of Mt. Cervia. Instead, the tectonic setting of the northernmost sector is denoted by the E-W boundary fault system that offsets the Upper Pliocene-Lower Pleistocene fluvio-lacustrine deposits towards the Rieti Plain (Figure 6c). Several normal faults are also labelled with movements in Pleistocene times, showing an intense tectonic fragmentation, possibly due to the superimposition of different tectonic phases.
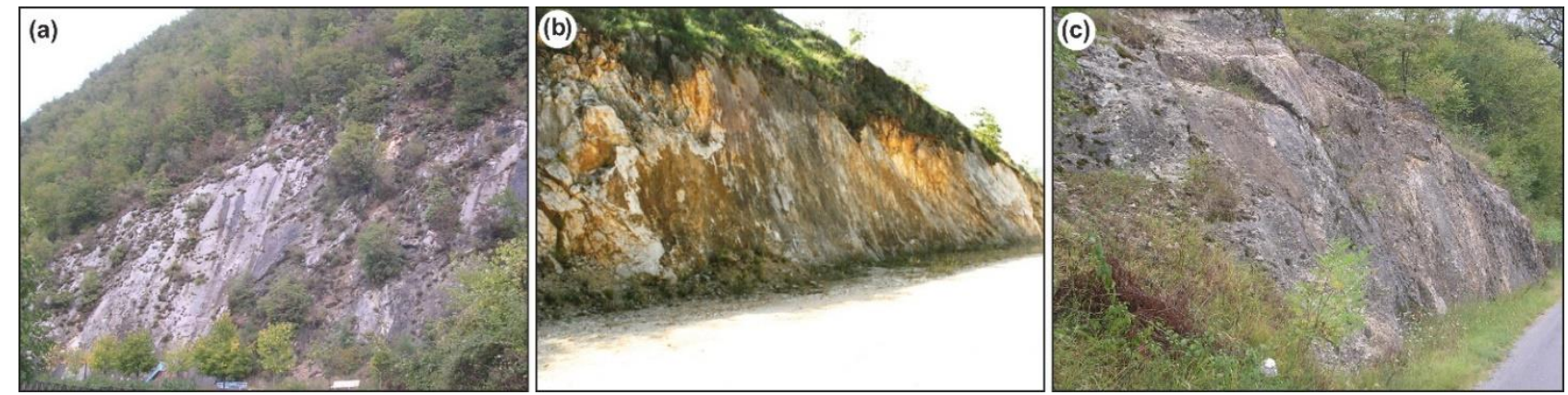

Figure 6. (a) NNW-SSE-oriented fault plane, located immediately above Ascrea village; (b) NNW-SSE-oriented fault plane, near Rocca Sinibalda village; (c) E-W-oriented fault plane, belonging to the Rieti Plain boundary fault system.

\subsection{Drainage System Development}

The drainage system evolution is strictly related to the tectonic framework and geomorphological evolution of the area, allowing to define the main steps of the Quaternary landscape evolution. The relationships between anomalies in the distributions of continental deposits, tectonic elements, and present-day drainage network provided significant evidence and constraints in the timing of drainage system development. This latter can be summarized in two main steps, spanning from Upper Pliocene to recent times, as graphically shown in Figures 7 and 8.

During Upper Pliocene-Lower Pleistocene, extensional tectonics, along NW-SE to NNW-SSE normal faults of Central Apennines, induced the development of several intramontane basins, outlining both an exoreic and endorheic drainage system [7].

In the Turano River basin, continental deposits are characterized by coarse-grained (gravel and conglomerate) deposits, mainly pertaining to a fluvial system, and fine-grained (silt and clay) deposits related to lacustrine environment. The combination of lithological features, depositional processes, and facies data allowed us to define the presence of an alluvial fan system and related paleolakes that filled the southern sector of the Rieti Plain and the Carsoli Plain. Moreover, a detailed drainage network analysis showed the central importance of paleoenvironmental settings in this first temporal step. Lithological and paleocurrent data (derived from clast imbrication and paleochannels) showed a direct correlation between conglomeratic deposits and alluvial fan systems and their initial channelization towards existing morphological depressions. According to the azimuthal orientation of paleocurrent data and the spatial distribution of continental deposits, the drainage pattern followed the main paleocurrent direction (NW-SE trend), evolving into a centripetal one in the Carsoli Plain. 


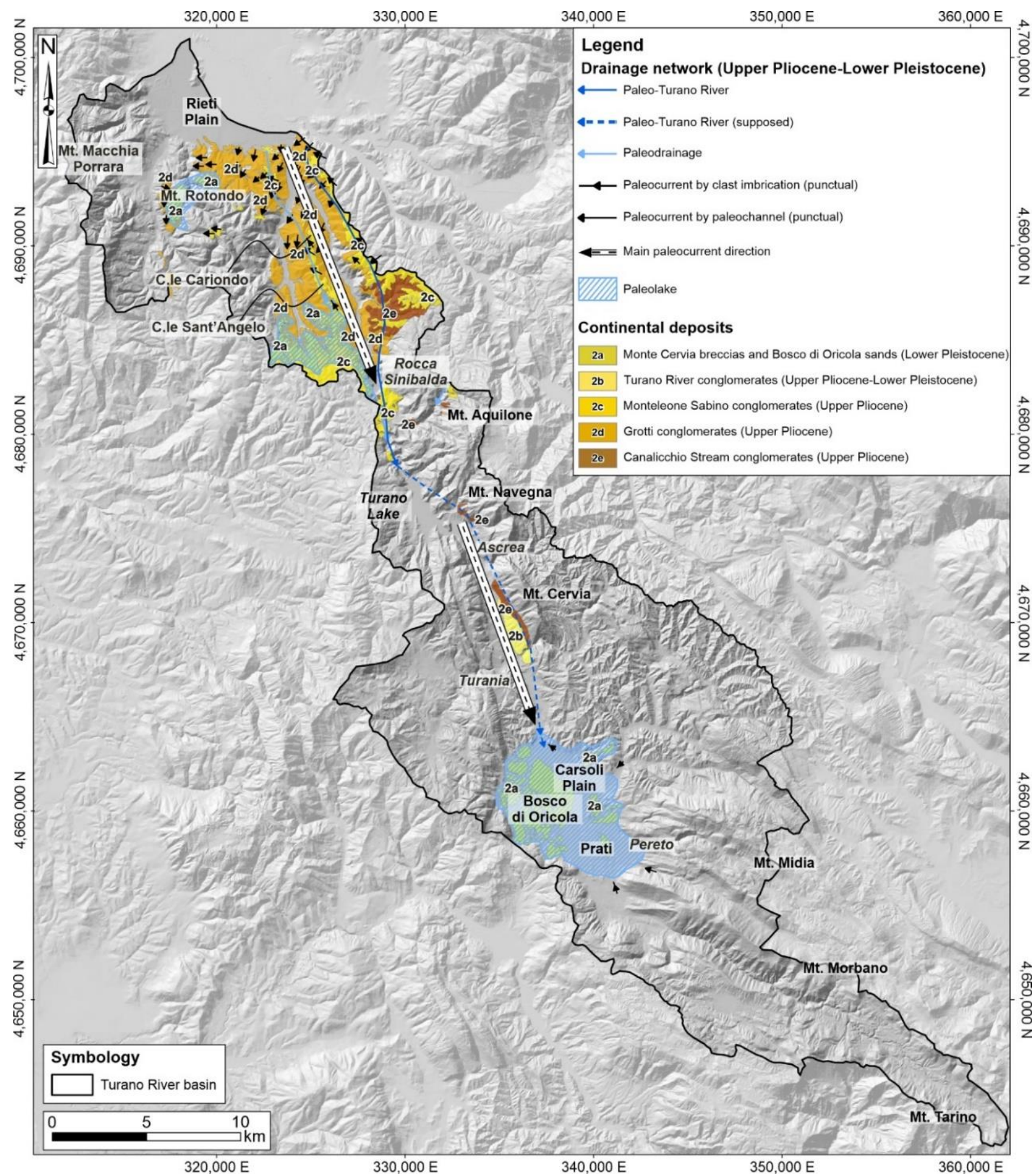

Figure 7. Drainage network of the Turano River from Upper Pliocene to Lower Pleistocene, mainly dominated by a NE-SW-oriented paleo-drainage. 


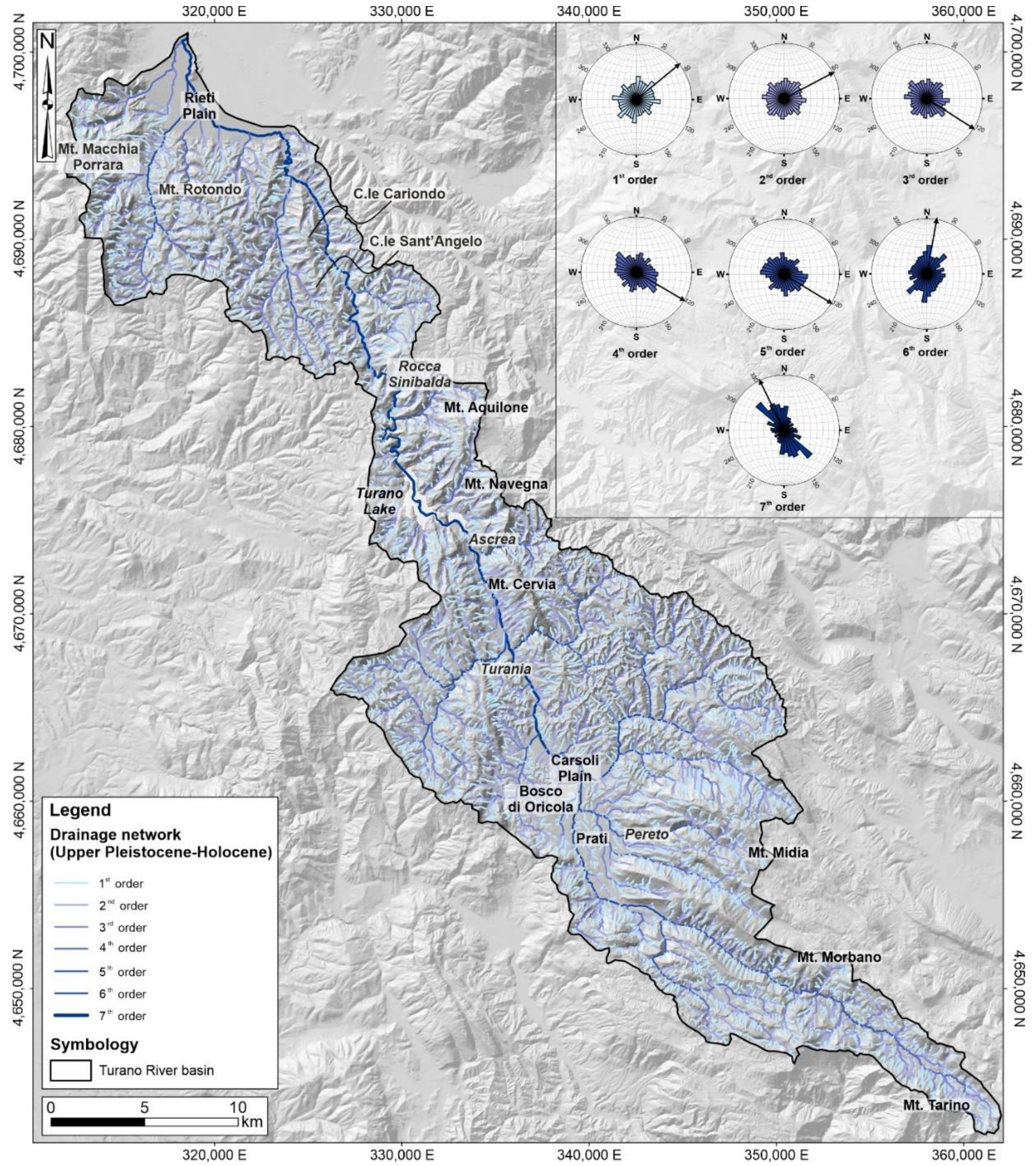

Figure 8. Drainage network of the Turano River from Upper Pleistocene to Holocene, mainly dominated by SE-NW-oriented drainage. Frequency-weighted rose diagrams show the azimuthal direction for each stream order of the Turano River, with black arrows indicating the mean vectors.

Furthermore, a GIS-based analysis, carried out to map and correlate continental deposits, pointed out that conglomeratic deposits (units from $2 \mathrm{e}$ to $2 \mathrm{~b}$; for detail, see legend in Figure 7) preserve an overall SE-oriented sense of flow. This assumption, combined with lithological features of lacustrine deposits outcropping at Bosco di Oricola (unit 2a; for detail, see legend in Figure 7), allowed us to infer an initial evolution of the Turano drainage system dominated by an NW-SE-oriented paleo-drainage, moving from the Ri- 
eti Plain towards the Carsoli Plain. During Middle Pleistocene, the dynamic interaction between tectonic processes, regional uplifting, and geomorphological processes resulted in a strong drainage system rearrangement. In the Turano River basin, this geologicalgeomorphological framework is testified by significant changes in the depositional environments (from alluvial fan to fluvial plain) and in the paleo-drainage pattern (from NW-SE to SE-NW). In detail, continental deposits are mainly referable to fluvial and volcanic environments. Fluvial deposits are characterized by gravels, sands, and silts (1n and 11 units; for detail, see legend in Figure 4). Volcanic deposits, dated about 0.531 My-0.540 My ago (Bosco di Oricola [3] and Cupaello [87]), are characterized by a sequence of pyroclastic flow, surge, and airfall products (unit 1m; for detail see legend in Figure 4), connected with a Middle Pleistocene intrapenninic monogenic volcanism. The drainage system underwent an abrupt change from an endorheic drainage system to an open through-going drainage system outlined by river incision and the development of fluvial terraces entrenched within the basin and surrounding areas.

The present-day drainage network mainly reflects the landscape evolution that occurred from the Upper Pleistocene to recent times (Figure 8). It is strictly related to the drainage system development that confirms the drainage network reversal process from an NW-SE-oriented paleo-drainage to the current SE-NW trend. In detail, continental deposits record a slight or accentuated gradient towards NW, confirming an NW sense of flow. Furthermore, it is possible to correlate these coarse- to fine-grained deposits to different genetic geomorphological environments (i.e., slope, fluvial, alluvial fan, and eluvial-colluvial), pointing to a complex landscape evolution. It results from dynamic interrelations between morphostructural factors linked to tectonic activity (compressive, strike-slip, and extensional tectonics) and regional uplift and morphosculptural factors linked to drainage network linear down-cutting and slope gravity processes.

The Turano River first flows in an E-W direction, receiving numerous contributions from secondary streams and minor ephemeral channels. Then, in correspondence of the Carsoli Plain, it flows linearly in the SSE-NNW direction, up to the Turano Lake, moving with a meandering course towards the Rieti Plain. Its drainage basin covers an area of $\sim 447 \mathrm{~km}^{2}$, showing different types of drainage patterns: a mainly trellis drainage pattern in the southernmost mountainous sector and a generally sub-dendritic one in the remaining portions. Moreover, its hierarchical drainage system organization is characterized by drainage lines ranging from the first to seventh order, according to [58] (Figure 8).

Frequency-weighted rose diagrams of first- and second-order streams mainly show an SW-NE direction; starting from the third order, the main trends are NW-SE (third, fourth, and fifth); the sixth and seventh order streams mainly reflect the present-day Turano River sense of flow, showing an average N-S azimuthal orientation with directions ranging from SW-NE to SE-NW trends (Figure 8).

\section{Discussion}

The study of drainage network rearrangements provides the key to understanding past and future landscape evolution. Drainage network evolves as a dynamic system, adjusting itself in response to perturbations in the landscape, generally associated with tectonic activity $[88,89]$. Continental deposits record such spatio-temporal perturbations; hence, Plio-Pleistocene stratigraphic frameworks have been generally recognized as fundamental elements to constrain geological paleo-events chronologically. Even if the reconstruction of ancient drainage systems is often hampered by the scattered distribution of poorly preserved outcrops of continental deposits, integrated geomorphological and morphometric investigations offer insights for drainage network analysis and paleoenvironmental reconstructions.

Previous studies have been carried out to reconstruct lithostratigraphic features, tectonic setting, and paleoenvironmental evolution of this mountainous sector of Central Apennines. Most aimed to characterize and describe the Plio-Pleistocene continental sequences in their entire thickness, disposition, and horizontal and vertical geome- 
tries [50,90-95]. However, existing relationships between paleo-drainage, continental deposits, and landscape evolution are still not completely understood. Here, we attempted to understand the impact on changes in fluvial behaviour and drainage system evolution of the Turano River basin (Central Apennines). Drainage network evolution was investigated through a preliminary synthesis and analysis of continental deposits based on essential data already available, recently verified by geological-geomorphological field surveys. An integrated GIS-based drainage network analysis allowed us to correlate geological data and fluvial environment in order to reconstruct the main steps of the Quaternary landscape evolution.

The generalized Turano River longitudinal profile of Figure 9 summarizes continental deposits' spatial and temporal arrangement, spanning from Upper Pliocene to Holocene. This simplified reconstruction was performed by plotting the discretely preserved spatial distribution of continental deposits from the upper stream toward the Rieti Plain. These deposits were correlated along the Turano River with locations displayed in the distance from source $[\mathrm{km}]$ and elevations above the sea level $[\mathrm{m}]$. This approach allowed us to identify and recognize two different drainage directions over time.

\section{SE}

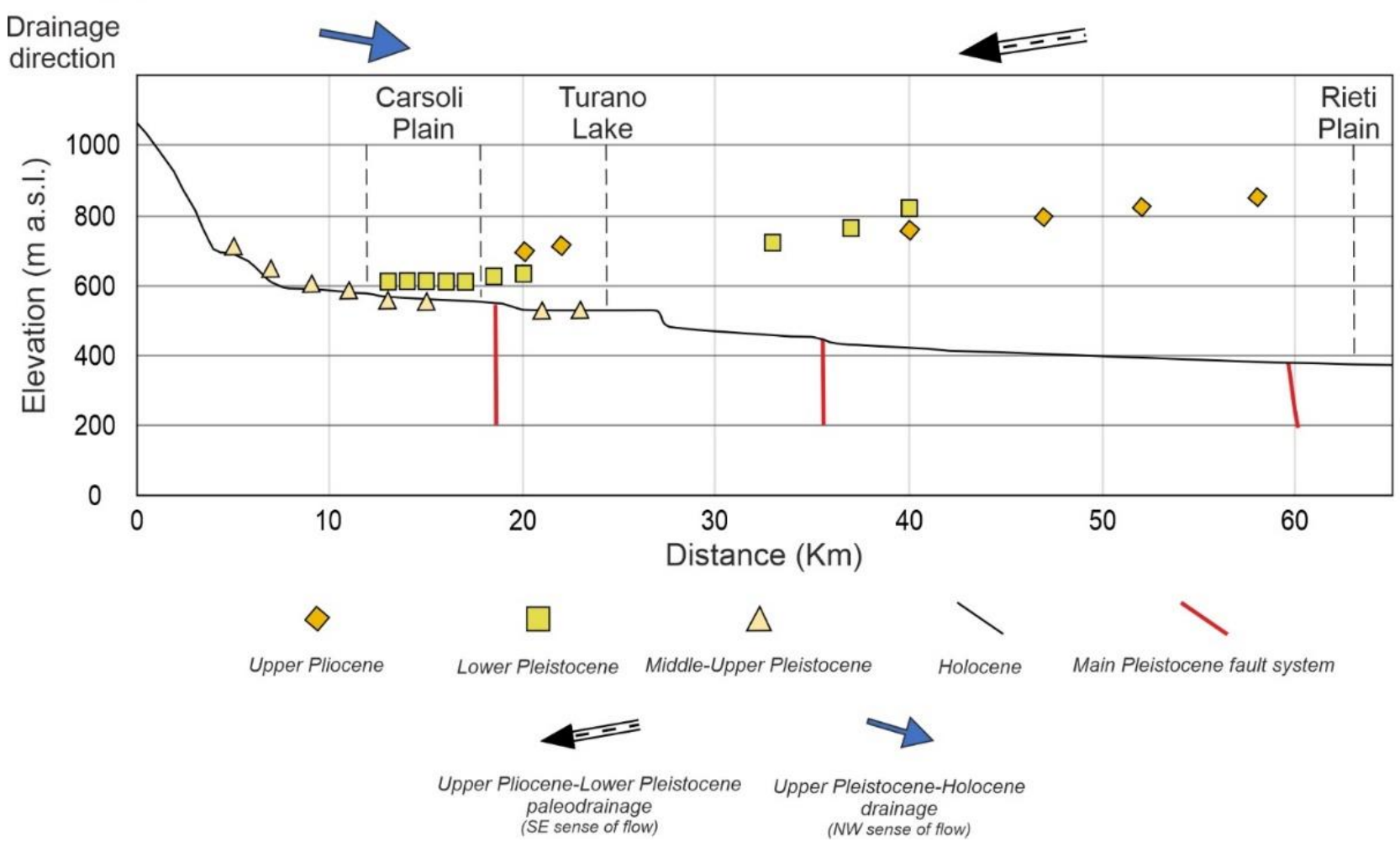

Figure 9. Generalized reconstruction of the longitudinal profile segment of the Turano River and its continental deposits. This simplified reconstruction was performed plotting the spatial arrangement of continental deposits from the uppermost stream, near Mt. Tarino (see also Figure 4), to the Velino River junction, within the Rieti Plain.

Taking into account the continental deposits' spatial distribution (as graphically shown in Figure 4), the upper segment of the paleo-drainage basin located at the northern sector of the Turano River basin presents a wide distribution and good preservation of old alluvial units, dating back to the upper Pliocene, while the lower segment preserves younger fluvial and alluvial units, dating back to the Middle to lower Pleistocene. This preservation pattern is contrast to the normal trend of deposition, usually accumulating in the down-stream segment, offering valuable suggestions to delineate the drainage network reversal process. 
Continental deposits can be generally divided into an NW-SE-oriented drainage direction, testifying a paleo-drainage towards the Carsoli Plain, and an SE-NW-oriented drainage direction, describing the present-day drainage towards Rieti Plain. Continental deposits related to the SE sense of flow can be grouped into different units, including fluvial (from 2e to 2b; for detail, see legend in Figure 4) and lacustrine deposits (2a; for detail, see legend in Figure 4). On the other hand, continental deposits related to NW sense of flow include 12 units (from 1n to 1a; for detail see legend in Figure 4), mainly referable to different depositional environments (i.e., slope, landslide, alluvial fan, eluvialcolluvial, glacial, and volcanic). These deposits mainly consist of heterometric calcareous and arenaceous gravels, conglomerate, and breccias with sandy and silty levels.

Considering lithological features and paleocurrent data, it was possible to perform a detailed investigation of the drainage network evolution. In detail, Upper PlioceneLower Pleistocene conglomeratic deposits preserve an overall SE-oriented sense of flow. An analysis of clasts imbrications, indicating S-oriented paleocurrents, combined with lithological features of lacustrine deposits outcropping at Carsoli Plain, allowed us to infer an initial evolution of the Turano drainage system dominated by an NE-SW-oriented paleo-drainage, moving from the Rieti Plain towards the Carsoli Plain. From Middle Pleistocene to Holocene, continental deposits outcrop with a general NW direction, in the same flow direction of the present day, suggesting that tectonic control acted as the main factor driving drainage inversion in the area. Morphological evidence of this latter control, slightly marked by simplified knickpoints, can also be derived by the spatial localization of the main Pleistocene fault systems (Figure 9) along the generalized longitudinal profile segment present-day Turano River.

The Turano River is a typical example of drainage network reversal, as clearly highlighted by analyzing the spatial arrangement of continental deposits. A thick continental deposits layer, which is found in the Carsoli Plain, can suggest an opposite paleo-drainage network. The three oldest units of continental deposits refer to an alluvial fan environment belonging to a Paleo-Turano River.

In fact, until the late Lower Pleistocene, the drainage direction followed an NW-SE trend towards the Carsoli Plain filled by a paleolake, as evidenced by the presence of lacustrine deposits. Then, the drainage changed, flowing towards the Rieti Plain, with an NW direction $[7,47,92]$. In Lower-Middle Pleistocene, owing to the rapid tectonic uplift that affected the entire chain area of the central Apennines [41], there was a substantial increase in linear erosion of the rivers, with a rapid deepening of the valley engraving [4]. Probably owing to regressive erosion, the Paleo-Turano River reaches the banks of the Carsoli Plain, opening a passage in the northern area [47], causing the emptying of the paleolake and leading to the development of a drainage network flowing in an NW-direction. In fact, from Upper Pleistocene to recent times, continental deposits record a slight or accentuated gradient towards NW, confirming an NW sense of flow.

In conclusion, the resulting correlations and analysis allowed us to confirm a southward flow of an earlier Turano River, opposite to the present northward gradient, providing better geomorphological constraints in the timing of this mountainous landscape evolution, clearly interested by a significant drainage network reversal. The adopted multidisciplinary approach allowed us to identify and describe the main steps of the Plio-Pleistocene landscape evolution of the Turano River basin. Moreover, this integrated approach (involving continental deposits analysis and geological-geomorphological field surveys) allowed us to better delineate the geomorphological and morphoneotectonic framework of the study area useful to support future territorial planning activities, especially for the Turano dam's management.

\section{Conclusions}

Morphogenetic study of river valleys provides knowledge of the evolution of the fluvial landscape, and it is a practical approach to understand current geomorphological processes. Continental deposits and morphological field evidence inherited from paleo- 
drainage record helpful information on landscape changes, offering insights for drainage network analysis and paleoenvironmental reconstructions. Investigating such fluvial landscapes is an opportunity to understand the Quaternary geomorphological dynamics and the processes that could determine drainage network rearrangements. The Turano River basin, located in the southwestern Abruzzo area at the boundary with Lazio Region, preserves lithological evidence particularly suitable for reconstructing the long-term geomorphological evolution of the Central Apennines.

The main aim of this work was to define the relationships between the present-day drainage network, the spatial distribution of continental deposits, and tectonic elements, providing geomorphological constraints in the timing of landscape evolution. In detail, a drainage basin-scale analysis that incorporates morphometric analysis, field mapping, continental deposits analysis, and integrated drainage network analysis was performed. This methodological approach allowed us to better define the drainage network reversal process, which characterized this mountainous landscape as clearly highlighted by the spatial arrangement of continental deposits, spanning from Upper Pliocene to Holocene. Several previous thematic studies $[4,7,11,12,19,36]$ widely describe both regional uplift and active extensional deformation with large-scale geological-structural, geomorphological, and tectonic analysis. According to these works, tectonic activity and regional uplift, which affected the entire chain area of the central Apennines, contributed as factors driving incision and river inversion in the landscape evolution of the area. The work contributes to understanding the geomorphological evolution of the area to identify and describe the main steps of the Plio-Pleistocene landscape evolution of the Turano River basin and its morphoneotectonic framework. Finally, it represents a scientific and methodological tool for multidisciplinary studies (incorporating Quaternary geology, applied geomorphology, and morphotectonics) in similar mountainous catchments, useful to support any territorial planning activity, from large infrastructure localization (i.e., artificial dams) to sustainable land management.

Author Contributions: Conceptualization, E.M., F.C., M.F., G.P.C. and M.D.; methodology, V.M., E.M., M.P. and F.C.; software, A.C., V.M., C.E., G.E. and G.P.; validation, G.P.C. and M.D.; investigation, E.M., F.C., M.D., M.P. and G.P.C.; writing—original draft preparation, V.M. and G.P.; writingreview and editing, V.M., G.P., G.P.C. and M.D.; supervision, E.M., M.P., G.P.C. and M.D.; project administration, E.M., G.P.C. and M.D.; funding acquisition, E.M. All authors have read and agreed to the published version of the manuscript.

Funding: This research and the APC were funded by Enrico Miccadei, grant provided by Università degli Studi "G. d'Annunzio" Chieti-Pescara.

Data Availability Statement: The data presented in this study are available on request from the author. The data are not publicly available due to privacy. Images employed for the study will be available online for readers.

Acknowledgments: The authors are glad to thank the anonymous reviewers that helped to greatly improve the manuscript with their precious suggestions and comments. The authors wish to thank the Struttura Speciale di Supporto Informatico Regionale (http:/ / www.regione.abruzzo.it/xcartografia/, accessed on 20 August 2020), the Open Geodata service (http: / / opendata.regione.abruzzo.it/, accessed on 20 August 2020) of Abruzzo Region, and Open Data (http:/ / dati.lazio.it/catalog/dataset, accessed on 20 August 2020) of Lazio Region for providing topographic data. As shown in Figure 2a, base data of lithological units were retrieved from Italian National Geoportal (WMS service available on: http://wms.pcn.minambiente.it/ogc?map=/ms_ogc/WMS_v1.3/Vettoriali/Carta_geolitologica. map; accessed on 10 September 2020). Color palette for continental deposits (Figures 4 and 7) were derived from Manuale Cromatico di riferimento per la stampa delle carte geologiche. Servizio Geologico d'Italia, Regione Emilia-Romagna-Servizio Geologico Sismico e dei Suoli, S.EL.CA. s.r.l. Firenze, SystemCart s.r.l., Roma (2002). The authors are grateful to Maurizio Parotto for the precious advice and suggestions that greatly improved the manuscript, and they wish to thank him with the following Italian form: " . . tutto iniziò con il Fiume Turano! Grazie Ad Majora".

Conflicts of Interest: The authors declare no conflict of interest. 


\section{References}

1. Huntington, K.W.; Klepeis, K.A. Challenges and Opportunities for Research in Tectonics: Understanding Deformation and the Processes that Link Earth Systems, from Geologic Time to Human Time; University of Washington: Seattle, WA, USA, 2018. [CrossRef]

2. Mancini, M.; Cavinato, G.P. The Middle Valley of the Tiber River, Central Italy: Plio-Pleistocene Fluvial and Coastal Sedimentation, Extensional Tectonics and Volcanism. In Fluvial Sedimentology VII; Blum, M.D., Marriot, S.B., Leclair, S.F., Eds.; International Association of Sedimentologists: Algiers, Algeria, 2005; pp. 373-396, ISBN 978-1-405-12651-9.

3. D'Orefice, M.; Graciotti, R.; Capitanio, F.; Stoppa, F.; Rosatelli, G.; Barbieri, M. Il vulcanismo medio-pleistocenico dell'Appennino Laziale-Abruzzese: Dalle peculiarità scientifiche agli aspetti applicativi. Mem. Descr. Della Cart. Geol. D'Ital. 2006, LXXII, 7-67.

4. D'Agostino, N.; Jackson, J.A.; Dramis, F.; Funiciello, R. Interactions between mantle upwelling, drainage evolution and active normal faulting: An example from the central Apennines (Italy). Geophys. J. Int. 2001, 147, 475-497. [CrossRef]

5. Miccadei, E.; Piacentini, T.; Buccolini, M. Long-term geomorphological evolution in the Abruzzo area, Central Italy: Twenty years of research. Geol. Carpathica 2017, 68, 19-28. [CrossRef]

6. Bartolini, C.; D’Agostino, N.; Dramis, A.F. Topography, exhumation, and drainage network evolution of the Apennines. Episodes 2003, 26, 212-216. [CrossRef] [PubMed]

7. Piacentini, T.; Miccadei, E. The role of drainage systems and intermontane basins in the Quaternary landscape of the Central Apennines chain (Italy). Rend. Lincei 2014, 25, 139-150. [CrossRef]

8. Vezzani, L.; Festa, A.; Ghisetti, F.C. Geology and tectonic evolution of the Central-Southern Apennines, Italy. In Special Paper of the Geological Society of America; Geological Society of America, Ed.; Geological Society of America: Boulder, CO, USA, 2010 ; p. 58.

9. Cosentino, D.; Asti, R.; Nocentini, M.; Gliozzi, E.; Kotsakis, T.; Mattei, M.; Esu, D.; Spadi, M.; Tallini, M.; Cifelli, F.; et al. New insights into the onset and evolution of the central Apennine extensional intermontane basins based on the tectonically active L'Aquila Basin (central Italy). GSA Bull. 2017, 129, 1314-1336. [CrossRef]

10. Miccadei, E.; Paron, P.; Piacentini, T. The SW escarpment of Montagna del Morrone (Abruzzi, Central Italy): Geomorphology of a fault-generated mountain front. Geogr. Fis. E Din. Quat. 2004, 27, 55-87.

11. Ascione, A.; Cinque, A.; Miccadei, E.; Villani, F.; Berti, C. The Plio-Quaternary uplift of the Apennine chain: New data from the analysis of topography and river valleys in Central Italy. Geomorphology 2008, 102, 105-118. [CrossRef]

12. Cowie, P.A.; Phillips, R.J.; Roberts, G.P.; McCaffrey, K.; Zijerveld, L.J.J.; Gregory, L.C.; Walker, J.F.; Wedmore, L.N.J.; Dunai, T.; Binnie, S.A.; et al. Orogen-scale uplift in the central Italian Apennines drives episodic behaviour of earthquake faults. Sci. Rep. 2017, 7, 44858. [CrossRef]

13. Lucchi, M.R.; Calderoni, G.; Carrara, C.; Cipriani, N.; Esu, D.; Ferreli, L.; Girotti, O.; Gliozzi, E.; Lombardo, M.; Longinelli, A.; et al. Late Quaternary record of the Rieti basin, central Italy: Paleoenvironmental and paleoclimatic evolution. G. Geol. 2000, 62, 105-136.

14. Borrelli, P.; Hoelzmann, P.; Knitter, D.; Schütt, B. Late Quaternary soil erosion and landscape development in the Apennine region (central Italy). Quat. Int. 2013, 312, 96-108. [CrossRef]

15. Mazzanti, R.; Trevisan, L. Evoluzione della rete idrografica nell'Appennino centro-settentrionale. Geogr. Fis. Din. Quat. 1978, $1,55-62$.

16. D'Alessandro, L.; Miccadei, E.; Piacentini, T. Morphostructural elements of central-eastern Abruzzi: Contributions to the study of the role of tectonics on the morphogenesis of the Apennine chain. Quat. Int. 2003, 101-102, 115-124. [CrossRef]

17. Miccadei, E.; Piacentini, T. Two Tectonic Geomorphology Studies on the Landscape and Drainage Network of Chain and Piedmont Areas of the Abruzzi Region (Central Apennines, Italy). In New Frontiers in Tectonic Research-At the Midst of Plate Convergence; Uri Schattner: Rijeka, Croatia, 2011; pp. 173-214.

18. Curzi, M.; Aldega, L.; Bernasconi, S.; Berra, F.; Billi, A.; Boschi, C.; Franchini, S.; Van Der Lelij, R.; Viola, G.; Carminati, E. Architecture and evolution of an extensionally-inverted thrust (Mt. Tancia Thrust, Central Apennines): Geological, structural, geochemical, and K-Ar geochronological constraints. J. Struct. Geol. 2020, 136, 104059. [CrossRef]

19. Geurts, A.H.; Whittaker, A.C.; Gawthorpe, R.L.; Cowie, P.A. Transient landscape and stratigraphic responses to drainage integration in the actively extending central Italian Apennines. Geomorphology 2020, 353, 107013. [CrossRef]

20. Morais, E.S.; Cremon, É.H.; Santos, M.L.; Rocha, P.C. Late Pleistocene-Holocene landscape evolution in the lower Peixe river, Brazil: A meandering river valley. J. S. Am. Earth Sci. 2020, 102, 102664. [CrossRef]

21. Struth, L.; Garcia-Castellanos, D.; Viaplana-Muzas, M.; Vergés, J. Drainage network dynamics and knickpoint evolution in the Ebro and Duero basins: From endorheism to exorheism. Geomorphology 2019, 327, 554-571. [CrossRef]

22. Pavano, F.; Pazzaglia, F.J.; Catalano, S. Knickpoints as geomorphic markers of active tectonics: A case study from northeastern Sicily (southern Italy). Lithosphere 2016, 8, 633-648. [CrossRef]

23. Maroukian, H.; Gaki-Papanastassiou, K.; Karymbalis, E.; Vouvalidis, K.; Pavlopoulos, K.; Papanastassiou, D.; Albanakis, K. Morphotectonic control on drainage network evolution in the Perachora Peninsula, Greece. Geomorphology 2008, 102, 81-92. [CrossRef]

24. Valente, E.; Buscher, J.T.; Jourdan, F.; Petrosino, P.; Reddy, S.M.; Tavani, S.; Corradetti, A.; Ascione, A. Constraining mountain front tectonic activity in extensional setting from geomorphology and Quaternary stratigraphy: A case study from the Matese ridge, southern Apennines. Quat. Sci. Rev. 2019, 219, 47-67. [CrossRef]

25. Struth, L.; Giachetta, E.; Willett, S.D.; Owen, L.A.; Tesón, E. Quaternary drainage network reorganization in the Colombian Eastern Cordillera plateau. Earth Surf. Process. Landf. 2020, 45, 1789-1804. [CrossRef] 
26. Patacca, E.; Sartori, R.; Scandone, P. Tyrrhenian basin and Apenninic Arcs: Kinematic relations since Late Tortonian times. Mem. Soc. Geol. Ital. 1990, 45, 425-451.

27. Parotto, M.; Cavinato, G.P.; Miccadei, E.; Tozzi, M. Line CROP 11: Central Apennines. CROP Atlas: Seismic reflection profiles of the Italian crust. Mem. Descr. Della Cart. Geol. D'Ital. 2003, LXII, 145-163.

28. Bosi, C.; Galadini, F.; Giaccio, B.; Messina, P.; Sposato, A. Plio-Quaternary continental deposits in the Latium-Abruzzi Apennines: The correlation of geological events across different intermountain basins. Il Quat. 2003, 16, 55-76.

29. Galadini, F.; Messina, P. Early-Middle Pleistocene eastward migration of the Abruzzi Apennine (central Italy) extensional domain. J. Geodyn. 2004, 37, 57-81. [CrossRef]

30. Gori, S.; Falcucci, E.; Ladina, C.; Marzorati, S.; Galadini, F. Active faulting, 3-D geological architecture and Plio-Quaternary structural evolution of extensional basins in the central Apennine chain, Italy. Solid Earth 2017, 8, 319-337. [CrossRef]

31. Michetti, A.M.; Brunamonte, F.; Serva, L.; Whitney, R.A. Seismic hazard assesment from paleoseismological evidence in the Rieti Region (Central Italy). In Perspectives in Paleoseismology; Serva, L., Slemmonds, D.B., Eds.; Peanut Butter Publishing: Seattle WA, USA, 1995; pp. 63-82.

32. Cavinato, G.P.; Cosentino, D.; De Rita, D.; Funiciello, R.; Parotto, M. Tectonic-sedimentary evolution of intrapenninic basins and correlation with the volcano-tectonic activity in Central Italy. Mem. Descr. Della Cart. Geol. D'Ital. 1994, XLIX, 63-76.

33. Scrocca, D.; Doglioni, C.; Innocenti, F. Contraints for an interpretation of the italian geodynamics: A review. Mem. Descr. Cart. Geol. D'Ital. 2003, LXII, 15-46.

34. Mattei, M.; Conticelli, S.; Giordano, G. The Tyrrhenian margin geological setting: From the Apennine orogeny to the K-rich volcanism. Colli Albani Volcano 2018, 3, 7-27. [CrossRef]

35. Fubelli, G.; Seta, M.D.; Amato, G. Drainage system adjustment in response to the opening of the Rieti intermontane basin (Central Italy): Geostatistical reconstruction of the PaleoFarfa River alluvial plain. Rend. Lincei 2014, 25, 167-176. [CrossRef]

36. Geurts, A.H.; Cowie, P.A.; Duclaux, G.; Gawthorpe, R.L.; Huismans, R.S.; Pedersen, V.K.; Wedmore, L.N.J. Drainage integration and sediment dispersal in active continental rifts: A numerical modelling study of the central Italian Apennines. Basin Res. 2018, 30, 965-989. [CrossRef]

37. Marino, M.; Menotti, R.M.; Miccadei, E.; Moretti, P.; Motteran, G.; Russo, L.; Scalise, A.R.; Serafini, R.; Spogli, G. The Turano Lake and the Big Dam. A geological tour along the Turano road between the regions of Lazio and Abruzzo. Mem. Descr. Della Cart. Geol. d'Ital. 2014, 102, 87-100.

38. Mellini, F.; Petitta, M. Hydrogeological surveys to assess groundwater resoureces in the Middle Valley of Turano River (Central Italy). Ital. J. Eng. Geol. Environ. 2013, 2, 15-30.

39. Borrelli, P.; Maerker, M.; Panagos, P.; Schütt, B. Modeling soil erosion and river sediment yield for an intermountain drainage basin of the Central Apennines, Italy. Catena 2014, 114, 45-58. [CrossRef]

40. Borrelli, P.; Märker, M.; Schütt, B.; Maerker, M. Modelling Post-Tree-Harvesting Soil Erosion and Sediment Deposition Potential in the Turano River Basin (Italian Central Apennine). Land Degrad. Dev. 2013, 26, 356-366. [CrossRef]

41. Cavinato, G.P. Recent tectonic evolution of the Quaternary deposits of the Rieti Basin (central Apennines, Italy): Southern part. Geol. Rom. 1993, 29, 411-434.

42. Mancini, M.; Cavuoto, G.; Pandolfi, L.; Petronio, C.; Salari, L.; Sardella, R. Coupling basin infill history and mammal biochronology in a Pleistocene intramontane basin: The case of western L'Aquila Basin (central Apennines, Italy). Quat. Int. 2012, 267, 62-77. [CrossRef]

43. Miccadei, E.; Barberi, R.; Cavinato, G.P. La geologia quaternaria della Conca di Sulmona (Abruzzo, Italia Centrale). Geol. Romana 1998, 34, 59-86.

44. Miccadei, E.; Piacentini, T.; Barberi, R. Uplift and local tectonic subsidence in the evolution of intramontane basins: The ex-ample of the Sulmona Basin (Central Apennines, Italy). In Proceedings of the Large-Scale Vertical Movements and Related Gravitational Processes, Camerino, Rome, Italy, 21-26 June 1999; pp. 1134-1191.

45. Mondati, G.; Spadi, M.; Gliozzi, E.; Cosentino, D.; Cifelli, F.; Cavinato, G.P.; Tallini, M.; Mattei, M. The tectono-stratigraphic evolution of the Fucino Basin (central Apennines, Italy): New insights from the geological mapping of its north-eastern margin. J. Maps 2021, 17, 87-100. [CrossRef]

46. Barberi, R.; Cavinato, G.P.; Gliozzi, E.; Mazzini, I. Late Pliocene-Early Pleistocene palaeoenvironmental evolution of the Rieti Basin (Central Apennines). Alp. Mediterr. Quat. 1995, 8, 515-534.

47. D'Orefice, M.; Graciotti, R.; Chiessi, V.; Neri, P.C.; Morri, A.; Roma, M.; Falcetti, S. La conca intermontana di Oricola-Carsoli (AQ): Caratteri geologici, geomorfologici e applicativi. Mem. Descr. Della Cart. Geol. D'Ital. 2014, XCI, 1-138.

48. D'Orefice, M.; Dramis, F.; Graciotti, E.; Graciotti, R.; Soligo, M. Evoluzione geomorfologica quaternaria della conca intermontana di Carsoli (AQ). Alp. Mediterr. Quat. 2010, 23, 55-74.

49. D'Orefice, M.; Graciotti, R. Geological and geomorphological aspects of the central-western area of the Carsoli basin (L'Aquila, Italy). Geogr. Fis. E Din. Quat. 2005, 28, 181-191.

50. Guerrieri, L.; Brunamonte, F.; Comerci, V.; Ferreli, L.; Michetti, A.M.; Pompili, R.; Serva, L. Geological evolution of the intermountain Rieti basin (Central Apennines). In Mapping Geology in Italy; Pasquarè, G., Venturini, C., Groppelli, G., Eds.; SELCA: Firenze, Italy, 2004; pp. 123-130.

51. Fabbi, S.; Galluzzo, F.; Pichezzi, R.M. Carbonate intercalations in a terrigenous foredeep: Late Miocene examples from the Simbruini Mts. and the Salto Valley (Central Apennines-Italy). Ital. J. Geosci. 2014, 133, 85-100. [CrossRef] 
52. Rovida, A.; Locati, M.; Camassi, R.; Lolli, B.; Gasperini, P.; Antonucci, A. The Italian Earthquake Catalogue CPTI15-Version 3.0; Istituto Nazionale di Geofisica e Vulcanologia (INGV): Rome, Italy, 2021.

53. ISIDe Working Group. Italian Seismological Instrumental and Parametric Database (ISIDe); Istituto Nazionale di Geofisica e Vulcanologia (INGV): Rome, Italy, 2007.

54. Cosentino, D.; Miccadei, E.; Barberi, R.; Basilici, G.; Cipollari, P.; Parotto, M.; Piacentini, T. Note Illustrative Della Carta Geologica d'Italia Alla Scala 1:50,000, Foglio 357 "Cittaducale"; APAT—Servizio Geologico D'Itali: Rome, Italy, 2014; pp. 1-143.

55. Tarquini, S.; Isola, I.; Favalli, M.; Mazzarini, F.; Bisson, M.; Pareschi, M.T.; Boschi, E. TINITALY/01: A new Triangular Irregular Network of Italy. Ann. Geophys. 2007, 50, 407-425. [CrossRef]

56. Tarquini, S.; Vinci, S.; Favalli, M.; Doumaz, F.; Fornaciai, A.; Nannipieri, L. Release of a 10-m-resolution DEM for the Italian territory: Comparison with global-coverage DEMs and anaglyph-mode exploration via the web. Comput. Geosci. 2012, 38, 168-170. [CrossRef]

57. Strahler, A.N. Dynamic Basis of Geomorphology. GSA Bull. 1952, 63, 923-938. [CrossRef]

58. Strahler, A.N. Quantitative analysis of watershed geomorphology. Trans. Am. Geophys. Union 1957, 38, 913-920. [CrossRef]

59. Belisario, F.; Del Monte, M.; Fredi, P.; Funiciello, R.; Palmieri, E.L.; Salvini, F. Azimuthal analysis of stream orientations to define regional tectonic lines. Z. Fur Geomorphol. Suppl. 1999, 118, 41-63.

60. Charizopoulos, N.; Mourtzios, P.; Psilovikos, T.; Psilovikos, A.; Karamoutsou, L. Morphometric analysis of the drainage network of Samos Island (northern Aegean Sea): Insights into tectonic control and flood hazards. Comptes Rendus Geosci. 2019, 351, 375-383. [CrossRef]

61. ISPRA. Aggiornamento ed Integrazione delle Linee Guida della Carta Geologica d'Italia in scala 1:50,000. In Progetto CARG: Modifiche ed integrazioni al Quaderno n. 1/1992; Servizio Geologico D’Italia: Rome, Italy, 2009; Volume 12.

62. Babault, J.; Driessche, J.V.D.; Teixell, A. Longitudinal to transverse drainage network evolution in the High Atlas (Morocco): The role of tectonics. Tectonics 2012, 31, 1-15. [CrossRef]

63. Calmel-Avila, M.; Silva, P.; Bardají, T. Drainage system inversion in the Guadalentin Depression during the Late PleistoceneHolocene (Murcia, Spain). Adv. Stud. Desertif. Contrib. Int. Conf. Desertif. Mem. Profr. Jo/Coord. 2009, 1, 461-464. Available online: http:/ / congresos.um.es/icod/icod2009/paper/viewFile/4481/4631 (accessed on 19 March 2021).

64. Miccadei, E.; Piacentini, T.; Gerbasi, F.; Daverio, F. Morphotectonic map of the Osento River basin (Abruzzo, Italy), scale 1:30,000. J. Maps 2012, 8, 62-73. [CrossRef]

65. Miccadei, E.; Carabella, C.; Paglia, G.; Piacentini, T. Paleo-Drainage Network, Morphotectonics, and Fluvial Terraces: Clues from the Verde Stream in the Middle Sangro River (Central Italy). Geosciences 2018, 8, 337. [CrossRef]

66. Miccadei, E.; Berti, C.; Calista, M.; Esposito, G.; Mancinelli, V.; Piacentini, T. Morphotectonics of the Tasso Stream-Sagittario River valley (Central Apennines, Italy). J. Maps 2019, 15, 257-268. [CrossRef]

67. D'Alessandro, L.; De Pippo, T.; Donadio, C.; Mazzarella, A.; Miccadei, E. Fractal dimension in Italy: A geomorphological key to interpretation. Z. Für Geomorphol. 2006, 50, 479-499. [CrossRef]

68. Pasculli, A.; Palermi, S.; Sarra, A.; Piacentini, T.; Miccadei, E. A modelling methodology for the analysis of radon potential based on environmental geology and geographically weighted regression. Environ. Model. Softw. 2014, 54, 165-181. [CrossRef]

69. Nocentini, M.; Cosentino, D.; Spadi, M.; Tallini, M. Plio-Quaternary geology of the Paganica-San Demetrio-Castelnuovo Basin (Central Italy). J. Maps 2018, 14, 411-420. [CrossRef]

70. Forno, M.G.; Ferrando, S. Plio-Quaternary continental deposits of the Castellamonte area, between Orco and Dora Baltea Basins (Torino Province, Italy). Quat. Int. 2008, 190, 103-111. [CrossRef]

71. Fabbi, S. Geology of the Northern Simbruini Mts. (Abruzzo-Italy). J. Maps 2016, 12, 441-452. [CrossRef]

72. APAT. Carta Geologica d'Italia Alla Scala 1:50,000, Foglio 357 “Cittaducale”; ISPRA: Rome, Italy, 2012. Available online: https: / / www.isprambiente.gov.it/Media/carg/357_CITTADUCALE/Foglio.html (accessed on 22 September 2020).

73. ISPRA. Carta Geologica d'Italia Alla Scala 1:50,000, Foglio 357 "Cittaducale"; ISPRA: Rome, Italy, 2010. Available online: https: // www.isprambiente.gov.it/Media/carg/358_PESCOROCCHIANO/Foglio.html (accessed on 22 September 2020).

74. ISPRA. Carta Geologica d'Italia Alla Scala 1:50,000, Foglio 366 "Palombara Sabina"; ISPRA: Rome, Italy, 2020. Available online: https:/ / www.isprambiente.gov.it/Media/carg/366_PALOMBARA_SABINA/Foglio.html (accessed on 22 September 2020).

75. SGI. Carta Geologica d'Italia Alla Scala 1:50,000, Foglio 367 "Tagliacozzo"; ISPRA: Rome, Italy, 2005. Available online: https: //www.isprambiente.gov.it/Media/carg/367_TAGLIACOZZO/Foglio.html (accessed on 22 September 2020).

76. SGI. Carta Geologica d'Italia Alla Scala 1:50,000, Foglio 376 "Subiaco"; ISPRA: Rome, Italy, 1997. Available online: https://www. isprambiente.gov.it/Media/carg/376_SUBIACO/Foglio.html (accessed on 22 September 2020).

77. Keller, E.A.; Pinter, N. Active tectonics: Earthquakes, Uplift, and Landscape, 2nd ed.; Prentice Hall: Upper Saddle River, NJ, USA, $2002 ;$ p. 362.

78. Mayer, L.; Menichetti, M.; Nesci, O.; Savelli, D. Morphotectonic approach to the drainage analysis in the North Marche region, central Italy. Quat. Int. 2003, 101-102, 157-167. [CrossRef]

79. Merritts, D.J.; Vincent, K.R.; Wohl, E.E. Long river profiles, tectonism, and eustasy: A guide to interpreting fluvial terraces. J. Geophys. Res. Space Phys. 1994, 99, 14031-14050. [CrossRef]

80. Patacca, E.; Scandone, P.; Di Luzio, E.; Cavinato, G.P.; Parotto, M. Structural architecture of the central Apennines: Interpre-tation of the CROP 11 seismic profile from the Adriatic coast to the orographic divide. Tectonics 2008, 27. [CrossRef] 
81. Accordi, B.; Carbone, F. Carta delle litofacies del Lazio-Abruzzi ed aree limitrofe. CNR—Progetto Finalizzato "Geodinamica": Rome, Italy. Quad. Ric. Sci. 1988, 114, 223.

82. Parotto, M.; Praturlon, A. Geological summary of Central Apennines. In Structural Model of ltaly; Ogniben, L., Parotto, M., Praturlon, A., Eds.; Quaderni de La Ricerca Scientifica: Roma, Italy, 1975; Volume 90, pp. 257-311.

83. Cavinato, G.P.; Salvini, F.; Tozzi, M. Evoluzione strutturale del settore centrale della linea "Olevano-Antrodoco". Mem. Soc. Geol. Ital. 1986, 35, 591-601.

84. Roberts, G.P.; Michetti, A.M. Spatial and temporal variations in growth rates along active normal fault systems: An example from The Lazio-Abruzzo Apennines, central Italy. J. Struct. Geol. 2004, 26, 339-376. [CrossRef]

85. Compagnoni, B.; Galluzzo, F.; Santantonio, M. Osservazioni sulla tettonica e dati sulla litostratigrafia dei rilievi compresi nel Foglio 367 Tagliacozzo alla scala 1: 50,000. Boll. Serv. Geol. d'Ital. 1990, 109, 73-90.

86. Miccadei, E.; Parotto, M. Valle del Turano-Valle del Salto-Alta Valle del Velino. Le falde sabine, l'avanfossa messiniana e la linea tettonica Olevano-Antrodoco; le successioni sabine e la "soglia" del M. Nuria. Guid. Geol. Del Lazio 1993, 8, 208-228.

87. Laurenzi, M.; Stoppa, F.; Villa, L. Eventi ignei monogenici e depositi piroclastici nel distretto ultralcalino umbro-laziale \{ULUD\}: Revisione, aggiornamento e comparazione dei dati cronologici. Plinius 1994, 12, 61-66.

88. Giraudi, C. The Pliocene and Early Pleistocene drainage network evolution in the Monferrato Hills (Piedmont, NW Italy). Alp. Mediterr. Quat. 2018, 31, 21-35.

89. Bucci, F.; Santangelo, M.; Mirabella, F.; Mazzoni, A.; Cardinali, M. Drainage reversal revealed by geomorphometric analysis of fluvial terraces. Accepted abstracts. In Proceedings of the Geomorphometry 2020 Conference, Perugia, Italy, 13-17 September 2021; CNR Edizioni. pp. 209-211. [CrossRef]

90. Barberi, R.; Cavinato, G.P. Analisi sedimentologiche ed evoluzione paleogeografica del settore meridionale del Bacino di Rieti (Appennino Centrale). Stud. Geol. Camerti 1991, 39-53. [CrossRef]

91. Archer, C.; Noble, P.; Rosen, M.R.; Sagnotti, L.; Florindo, F.; Mensing, S.; Piovesan, G.; Michetti, A.M. Lakes as paleoseismic records in a seismically-active, low-relief area (Rieti Basin, central Italy). Quat. Sci. Rev. 2019, 211, 186-207. [CrossRef]

92. Chiarini, E.; D’Orefice, M.; Graciotti, R.; La Posta, E.; Papasodaro, F. Note Illustrative Della Carta Geomorfologica D'Italia Alla Scala 1:50,000, Foglio 367 “Tagliacozzo"; APAT—Servizio Geologico D’Italia: Rome, Italy, 2008; pp. 1-200.

93. Soligo, M.; Tuccimei, P.; Barberi, R.; Delitala, M.; Miccadei, E.; Taddeucci, A. U/Th dating of freshwater travertine from Middle Velino Valley (Central Italy): Paleoclimatic and geological implications. Palaeogeogr. Palaeoclim. Palaeoecol. 2002, 184, 147-161. [CrossRef]

94. Chiarini, E.; Giardini, M.; Mattei, M.; Papasordo, F.; Porreca, M.; Sadori, L. Plio-Quaternary geological evolution of the high Salto river valley (Central Italy): The Marano de'Marsi unit. Alp. Mediterr. Quat. 2009, 22, 325-344.

95. Borrelli, P.; Domdey, C.; Hoelzmann, P.; Knitter, D.; Panagos, P.; Schütt, B. Geoarchaeological and historical implications of late Holocene landscape development in the Carseolani Mountains, central Apennines, Italy. Geomorphology 2014, 216, 26-39. [CrossRef] 